\begin{tabular}{ccc}
\hline International Journal of Engineering \& Technology, $7(4.30)(2018) 350-354$ \\
SPC & Website: www.sciencepubco.com/index.php/IJET \\
Research paper & Technology \\
\hline
\end{tabular}

\title{
Chemical and Fresh State Properties of Foamed Concrete Incorporating Palm Oil Fuel Ash and Eggshell Ash as Cement Replacement
}

\author{
Sufian Kamaruddin', Wan Inn Goh ${ }^{1, *}$, Ashfaque Ahmed Jhatial' ${ }^{1}$, Muhammad Tahir Lakhiar ${ }^{1}$ \\ ${ }^{1}$ Jamilus Research Center, Faculty of Civil and.Environmental.Engineering,. Universiti Tun Hussein.Onn Malaysia, Batu Pahat 86400 , \\ Johor, Malaysia. \\ *Corresponding.author E-mail: wigoh@uthm.edu.com
}

\begin{abstract}
.
Malaysia faces three major environmental problems, out of which solid waste and management is one of them. Palm Oil Fuel Ash (POFA) and eggshells are two agro-food waste materials which are produced in enormous quantities in Malaysia. Due to the characteristics possessed by eggshells and POFA, these waste materials can potentially be utilized in the production as cement replacement, reducing the use of cement which is one of the major production of Carbon Dioxide $\left(\mathrm{CO}_{2}\right)$ gas emissions. This study was conducted to determine the chemical and fresh state properties of foamed concrete incorporating POFA and eggshell ash (ESA) as cement replacement. Based upon the results, it was observed that the increase in usage amount of POFA and ESA as cement replacement, the workability of foamed concrete reduced without blocking. For the chemical analysis result shows the POFA which had high amount of silicon dioxide and ESA having large amount of calcium oxide were compatible and could be used together as cement replacement. The use of ESA and POFA as cement replacement to reduce the cement consumption with various percentage of ESA $(0 \%-15 \%)$ and POFA $(20 \%-35 \%)$ in $1800 \mathrm{~kg} / \mathrm{m} 3$ density of foamed concrete.
\end{abstract}

Keywords: Chemical analysis; eggshell ash; fresh state properties; palm oil fuel ash.

\section{Introduction}

Concrete is one of the oldest manufactured construction material and.it has been used widely in the construction of various structure since ancient day. The continuous research and development of concrete has resulted.in the production of many types of concrete possesses own unique characteristic to meet and suit the demand of industry. Concrete is used in many different types in construction such as building frames, dams, bridges and other variety. Cement, water, and aggregate is a material mixture in concrete which must be workable, chemical resistance, low permeability, and economy [1].

Foamed concrete has been used and gained popularity in construction industry due to its excellent thermal and acoustics properties and lower self-weight [2] than conventional concrete. Reducing the density of concrete also can reducing the dead load and corresponding reduction in the size of concrete. It produced by the mixing of cement, sand, water, and performed stable foamed to generate small bubble of air into Portland cement. Characteristic of foamed concrete depends on the mix design there are however several general properties which are constant across a range of mix design. Due to its advantages in self-compacting, light weight, self-levelling nature, flow ability and low dimensional change, it has widely used in variety of lightweight non or semistructure [3].

In Malaysia, egg consumption of the people was recorded at 2.8 million eggs daily especially from chicken [4]. Hence, the egg consumption of Malaysian.is increasing with high demand for local food industry. Eggshells waste are seriously affecting the environment and causing pollution to public health.

POFA structure for chemical properties has high silica oxide but less proportion on calcium oxide compared to ESA which has high composition of calcium oxide and less content of silica oxide [5]. Therefore, the combination of supplementary material of POFA and ESA provide good composition of chemical properties as cement replacement.

Based upon their properties, the solid waste materials can either be used as supplementary cementitious materials or as replacement of fine aggregate in mortar or concrete. Therefore, recycling POFA and Eggshells into the useful product gives good potential for agricultural industry, food manufactured and a much wider construction industry. It is because by using waste product can reduce the cost of cement and manufacturing, but also has reduce the cost for land fill activity and reduce the pollution.

This research studies the chemical and fresh properties of foamed concrete incorporating POFA and eggshell ash as cement replacement. The sample specimens of $1800 \mathrm{~kg} / \mathrm{m} 3$ density foamed concrete containing POFA and Eggshells as partial cement replacement had been tested. The workability of fresh state foamed concrete was determined by J-Ring test. The foamed concrete was undergo X-Ray Fluorescence (XRF) test to determine its chemical composition. 


\section{Literature Review}

\subsection{Uses of Foamed Concrete}

The foamed concrete has good characteristic such as low density and high strength preferred normal concrete. Using foamed concrete reduces dead loads on the structure and foundation, contributes to energy conservation, and reduces the labor cost during construction. The use of foamed concrete as non-load bearing components has decreased the structural dead load based on compressive strength and its density. The decrease of dead load could lead to reduce the cost of production and transportation of building components and has the potential of being used as a structural material such as decreases the size of column and thickness of wall

Other applications include precast elements, in raft foundation of houses, as a foundation-layer for sports fields and athletic tracks, for annulus grouting of segmental tunnels, backfilling the voids behind tunnel linings, providing base for storage tanks or as blinding material.

\subsection{Material of Foamed Concrete}

\subsubsection{Ordinary Portland Cement (OPC)}

OPC is one of the most product used for a wide range of applications, including as general construction engineering and construction works, smaller works and even plastering works. OPC was classified.as type I cements [6]. It is suitable for all-purpose construction when there is no exposure to sulfate in soil or groundwater [7].

\subsubsection{Water}

From the constituents of the foamed concrete, water plays an important role in strength and durability of concrete. The strength of the concrete will reduce if the water contains the concentration of salt [8]. Generally, water used for mixing concrete have to be clean and does not contain any impurities that can affect the strength and durability of concrete. The most important factor to determine the strength that must be consider in concrete produce are the water cement ratio. The low water cement ratio is conducts to stronger concrete while the higher of water cements ratio will make the concrete become weak [9].

\subsubsection{Sand}

Sand is a fine, fragmented, naturally-occurring material containing of very small particles of decayed rocks, corals, or shells. Sand is used to provide bulk, strength, and other properties to construction materials like asphalt and concrete. River sand become the most used material in construction applications nowadays. Due to a small size, sand is very useful in concrete mix as a material for filling voids or cavity in concrete. River sand is known as material which is free from any chemical impurities or any substances that can affect the quality of concrete. The contents impurities can be shows by results of the dirt obtained while the sand is being touch by hand.

\subsubsection{Foam Agent}

Pre-foamed foam consists of two types which are wet foam and dry foam with forcing foaming agent through high density restrictions until create air compressed into mixing chamber and produced dry foam that size is smaller than $1 \mathrm{~mm}$ by using foam generator to produced foam. The bubble size of wet foam is larger than dry foam with the size of $2 \mathrm{~mm}$ to $5 \mathrm{~mm}$. In order to resists the pressure of mortar, the foam need to be firm and stable until strong concrete is construct around the void filled with air and cement takes its initial set.

\subsection{Supplementary Cementitious Materials}

\subsubsection{Palm Oil Fuel Ash}

With the continuously to increase production of palm oil in Malaysia, there will be produced more solid waste by-product of POFA with measured as nuisance to environment and disposed without any other use compared to other type of palm oil byproduct. It will be created a severe environmental problem in the future if there are failure to find any solution in making use of this by-product. In order to overcome this problem, many studies from researches proved that the waste by-product of POFA can be reutilized as cement replacement material or aggregate in concrete due to it pozzolanic properties possesses [10-13]

\subsubsection{Eggshell Ash}

Eggshell consists of composition compounds of calcium with the calcium carbonate $\left(\mathrm{CaCO}_{3}\right)$ is the major composition of eggshell. In the cement, the primary material in production of cement is calcium carbonate $\left(\mathrm{CaCO}_{3}\right)$. OPC contains of four main composition of calcium compounds which is dicalcium silicate $\left(\mathrm{C}_{2} \mathrm{~S}\right)$, tricalcium aluminate $\left(\mathrm{C}_{3} \mathrm{~A}\right)$, tricalcium silicate $\left(\mathrm{C}_{3} \mathrm{~S}\right)$ and tetracalcium aluminoferite $\left(\mathrm{C}_{4} \mathrm{AF}\right)$. Therefore, the composition of ESA and OPC has the same primary composition of calcium. The eggshell can be used and increasing the strength properties of concrete in addition reducing and solving the problem about eggshell waste materials proved that in construction purpose and application [14-18].

\section{Experimental Program}

\subsection{Material Preparation}

This research is mainly on the application of the eggshell ash and POFA as cement replacement material in mixing compound of foamed concrete. It contains types of material which is OPC, ESA POFA, sand, water and foaming agent. The ESA and POFA materials was used in the concrete composition according to the designed density. The preparation of materials and specimens is the process of selection appropriate materials and good quality to produce a good sample of concrete mix. The materials are used to determine whether the experiment is a success or a failure.

\subsubsection{Cement}

Ordinary Portland Cement (OPC) is the most common cement used in all-purpose concrete construction when there is no exposure to sulphate in the soil or ground water. This experimental work will use OPC categorized of Type 1 . The rheological and strength characteristics especially use in grouping with chemical admixtures and supplementary cementing materials is different. The Portland cement can be get at the market or it is provided in UTHM laboratory for the project purposes and was certified by SIRIM compliance to MS 197-1:2007.

\subsubsection{Palm.Oil Fuel Ash}

The palm oil fuel ash (POFA) that was used in this study collected from Ban Dung P.O Ind. Sdn. Bhd, Seri Medan, Batu Pahat, Johor as shown in Fig. 1. The POFA is a part of burning palm oil shells, husk, fibre and the non-combustible residues of combustion in a furnace or incinerator process. The POFA will be collected from combustion plant which expose to uncontrolled moisture condition was oven dried at $105{ }^{\circ} \mathrm{C}$ for 24 hours, sieved $300 \mu \mathrm{m}$ to remove unwanted particle and impurities material. The POFA will be grinded and sieved using $75 \mu \mathrm{m}$ for finess as cement replacement. 


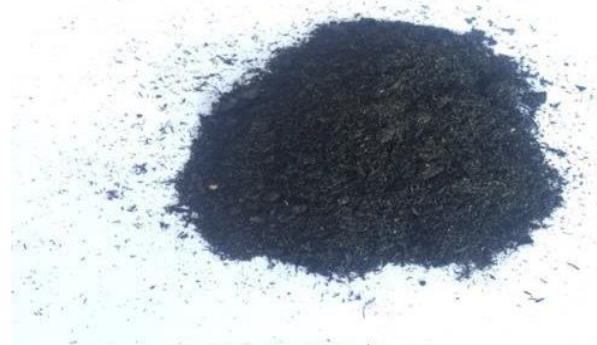

Fig. 1: Palm oil Fuel Ash

\subsubsection{Eggshell Ash}

Egg Shells collected from Federal Agricultural Marketing Authorities (FAMA), Rengit and bakery shops around Parit Raja, was used as a cement additional in this study as shown in Fig. 2. The egg shells were cleaned with normal water and left to dry in open air for 24 hours and then put in oven to dry for another 24 hours at a constant temperature of $105{ }^{\circ} \mathrm{C}$. Then the eggshells were grinded into powder such that the eggshell ash pass through $75 \mu \mathrm{m}$ sieve.

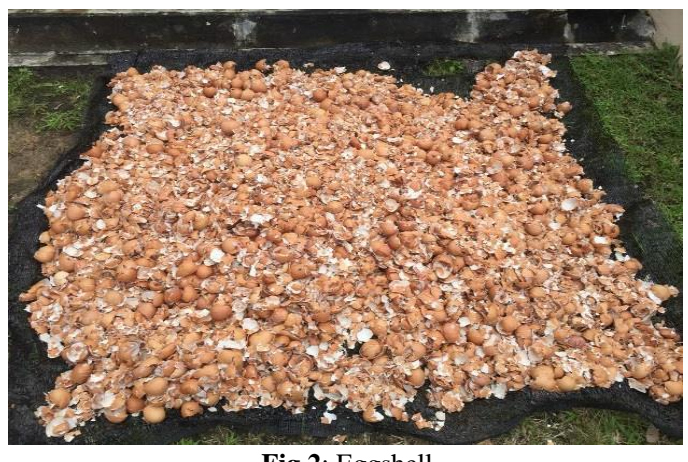

Fig.2: Eggshell

\subsection{Specimen Preparation}

\subsubsection{Mix Proportion}

By assuming a given target plastic density, water/cement ratio, POFA, ESA and cement percent, the total mix water and fine sand was calculated. In this study, the density of foamed concrete was fixed as $1800 \mathrm{~kg} / \mathrm{m} 3$.

The ratio of cement content, sand content and water content of the base mix which was used throughout this research is 1:2:0.55 while the ratio of foaming agent is $1: 20$ of water. The mix proportion of POFA and ESA to be replace as cement in foamed concrete content for each batch is shown in Table 1.

Table 1: POFA and ESA percentage for each sample

\begin{tabular}{|l|c|c|c|c|}
\hline \multicolumn{1}{|c|}{ Mix Name } & $\begin{array}{c}\text { POFA } \\
(\%)\end{array}$ & $\begin{array}{c}\text { ESA } \\
(\%)\end{array}$ & $\begin{array}{c}\text { Total Cement } \\
\text { Replacement }(\%)\end{array}$ & Cement $(\%)$ \\
\hline FC Controlled & 0 & 0 & 0 & 100 \\
FC P20 E0 & 20 & 0 & 20 & 80 \\
FC P20 E5 & 20 & 5 & 25 & 75 \\
FC P20 E10 & 20 & 10 & 30 & 70 \\
FC P20 E15 & 20 & 15 & 35 & 65 \\
FC P25 E5 & 25 & 5 & 30 & 70 \\
FC P25 E10 & 25 & 10 & 35 & 65 \\
FC P25 E15 & 25 & 15 & 40 & 40 \\
FC P30 E5 & 30 & 5 & 35 & 65 \\
FC P30 E10 & 30 & 10 & 40 & 60 \\
FC P30 E15 & 30 & 15 & 45 & 60 \\
FC P35 E5 & 35 & 5 & 40 & 55 \\
FC P35 E10 & 35 & 10 & 45 & 50 \\
FC P35 E15 & 35 & 15 & 50 & 5 \\
\hline
\end{tabular}

Note: $\mathrm{FC}=$ Foamed Concrete, $\mathrm{P}=$ Palm Oil Fuel Ash and E = Eggshells Ash

\subsubsection{Mixing Procedure}

The mixing procedure for this study is following the general practices for the normal concrete mixing and all the method was carried out manually. OPC, POFA, ESA and sand was weighted and mixed in a concrete mixer until the dry mix was consistently mixed. After that, water was weighted and added into the dry mix until wet mix was uniformly mixed. Then, an amount of foam was weighted and added into the wet mix repeatedly until the desired density of $1800 \mathrm{~kg} / \mathrm{m}^{3}$ was achieved. Lastly, determine the fresh of foamed concrete for workability.

\subsection{Chemical Properties Test}

$\mathrm{XRF}$ is used in some laboratories in forensic investigation of concrete to determine the elemental chemical composition of samples. $\mathrm{XRF}$ is for chemical compositions investigation of concrete sample and material replacement. In this study, XRF analysis will performed to study the chemical composition of OPC, POFA and ESA. The atoms of the sample were absorbed energy from the Xrays, become temporarily excited and then emit secondary $\mathrm{X}$-rays. Each chemical element emits $\mathrm{X}$-rays at a unique energy. The $\mathrm{X}$ ray Fluorescence Analyzer can deliver qualitative and quantitative analysis regarding the thickness and composition of the material being tested by measuring the strength and characteristic energy of the emitted X-rays.

\subsection{Workability Test}

This test technique covers determination of the passing ability of self-consolidating concrete by using the J-Ring in combination with a slump cone mold. The test method is restricted to concrete with maximum size of aggregate of $25 \mathrm{~mm}$. The J-ring test can be used in combination with the slump flow test to evaluate the ability of passing through steel bars of self-compacting concrete [19]. The difference between the flow diameters in the two tests was measured and denoted as PA. The value of PA should not exceed $50 \mathrm{~mm}$ for the concrete to achieve sufficient flow through the steel bars [20]. The J-ring consists of a steel circular ring and 16 round steel rods with $16 \mathrm{~mm}$ in diameter and $100 \mathrm{~mm}$ in height. Then the 16 rods were welded on the circular ring with equal spacing as shown in Fig. 3. It conforms to the ASTM C 1621/C $1621 \mathrm{M}^{1}$ guideline [21].

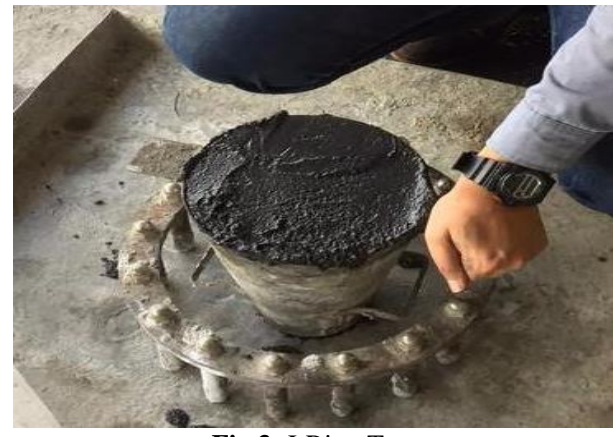

Fig.3: J-Ring Test

\section{Result and Discussion}

\subsection{Chemical Analysis}

X-Ray Fluorescence was study to determine elemental chemical composition of concrete sample as cement replacement. In this study, XRF analysis was performed to study the chemical composition of Ordinary Portland Cement, POFA and ESA. As seen in Table 2 Ordinary Portland Cement is most high content with calcium oxide $(\mathrm{CaO})$ and silicon dioxide $\left(\mathrm{SiO}_{2}\right)$. Chemical composi- 
tion of POFA is high with Silicon dioxide $\left(\mathrm{SiO}_{2}\right)$ and ESA high with Calcium Oxide $(\mathrm{CaO})$ [22-23].

Table 2: Chemical composition of OPC, POFA, ESA

\begin{tabular}{|l|c|c|c|}
\hline \multicolumn{1}{|c|}{ Chemical Composition } & OPC $(\%)$ & POFA (\%) & ESA (\%) \\
\hline Calcium Oxide $(\mathrm{CaO})$ & 57.30 & 4.86 & 68.00 \\
Silicon dioxide $\left(\mathrm{SiO}_{2}\right)$ & 14.10 & 31.10 & 0.33 \\
Carbon $(\mathrm{C})$ & 0.10 & 0.10 & 0.10 \\
Sulphur oxide $\left(\mathrm{SO}_{3}\right)$ & 3.81 & 1.34 & 0.68 \\
Aluminium Oxide $\left(\mathrm{Al}_{2} \mathrm{O}_{3}\right)$ & 3.68 & 1.39 & - \\
Ferric oxide $\left(\mathrm{Fe}_{2} \mathrm{O}_{3}\right)$ & 2.08 & 4.56 & - \\
Magnesium oxide $(\mathrm{MgO})$ & 1.87 & 1.88 & 0.48 \\
Potassium oxide $\left(\mathrm{K}_{2} \mathrm{O}\right)$ & 0.32 & 8.23 & - \\
Titanium $(\mathrm{Ti})$ & - & - & - \\
Phosphorus pentoxide & - & 2.58 & 0.35 \\
$\left(\mathrm{P}_{2} \mathrm{O}_{5}\right)$ & \multicolumn{3}{|c}{} \\
\hline
\end{tabular}

The material is attributed to the chain of reactions happening between the pozzolans i.e. palm oil fly ash (POFA) and water. The amorphous structure of POFA stimulates the pozzolanic reactivity, as the alkaline activators cement, and alkalis (Sodium and Potassium) acts as a catalyst. The amorphous $\mathrm{SiO}_{2}$ present in POFA forms low basicity calcium silicate hydrate gel (C-S-H). The existence of $\mathrm{CaO}$ in ESA react with water to form a hydrated gel. Palm oil fly ash (POFA) also acts as a source of siliceous and aluminous material forms silicate and aluminate hydrates when reacted with calcium hydroxide in the presence of moisture, which will be developed strength. The reaction happened during the hydration process is as follows equation 1 and 2 .

$\mathrm{CaO}+\mathrm{H}_{2} \mathrm{O}=\mathrm{Ca}(\mathrm{OH})_{2}$

$\mathrm{Ca}(\mathrm{OH})_{2}+\mathrm{SiO}_{2}+\mathrm{H}_{2} \mathrm{O}=\mathrm{C}-\mathrm{S}-\mathrm{H}$
Due to the characteristics possessed by POFA and ESA, these waste materials can be utilized in the production as cement replacement, reducing the use of cement which is one of the major production of Carbon Dioxide $\left(\mathrm{CO}_{2}\right)$ gas emissions.

\subsection{Fresh State Properties}

\subsubsection{Workability}

The J-ring test was conducted to determine the workability of foamed concrete incorporating POFA and ESA as partial cement replacement. The test was performed according to the guidelines prescribe in ASTM C 1621/C 1621M1. Table 3 shows the result of J-ring test from foamed concrete.

Based on the J-ring result, it can be seen that the control sample of foamed concrete has the maximum flow ability [19]. It also observed that the flow ability of foamed concrete reduces with the increase in cement replacement. This reduction in workability is due to the presence of POFA and eggshell ash the porous structure of surface area in foamed concrete which absorb the water and the foam resulting in less flow ability. Moreover, the properties colour of POFA is blackish causes it to absorb more water while reducing the size of diameter to achieve the target density of mix proportions which contain more POFA and ESA required more amount of foam then the control sample and the sample which contain less of POFA and ESA. The smallest diameter difference between slump flow and J-ring flow is FC Controlled which was approximately $11 \mathrm{~mm}$. Whereas the biggest diameter difference between slump flow and J-ring flow observed by FC P30 E15, FC P35 E10, FC P35 E15 which was $21 \mathrm{~mm}$. While the average of diameter difference is $17.3 \mathrm{~mm}$. All the J-ring results which were recorded in Table 3 have difference of 0 to $25 \mathrm{~mm}$ between slump flow and J-ring flow and had no visible blocking.

Table 3: The result of J-ring test of each mix proportion

\begin{tabular}{|c|c|c|c|c|c|c|c|c|}
\hline \multirow[b]{2}{*}{$\begin{array}{l}\text { Mix Propor- } \\
\text { tion }\end{array}$} & \multicolumn{3}{|c|}{ Slump Flow } & \multicolumn{3}{|c|}{ J-Ring Flow } & \multirow{2}{*}{$\begin{array}{c}\text { Difference } \\
\text { between } \\
\text { Slump and } \\
\text { J-Ring Flow } \\
\text { (mm) }\end{array}$} & \multirow[b]{2}{*}{$\begin{array}{l}\text { Type of } \\
\text { Blocking }\end{array}$} \\
\hline & d1 (mm) & d2 (mm) & $\frac{d 1+d 2}{2}$ & d1 (mm) & d2 (mm) & $\frac{d 1+d 2}{2}$ & & \\
\hline FC Control & 533 & 528 & 531 & 520 & 520 & 520 & 11 & No blocking \\
\hline FC P20 E0 & 430 & 428 & 429 & 425 & 400 & 413 & 16 & No blocking \\
\hline FC P20 E5 & 398 & 390 & 394 & 385 & 370 & 378 & 16 & No blocking \\
\hline FC P20 E10 & 383 & 377 & 380 & 370 & 360 & 365 & 15 & No blocking \\
\hline FC P25 E5 & 419 & 415 & 417 & 415 & 390 & 403 & 14 & No blocking \\
\hline FC P25 E10 & 399 & 397 & 398 & 385 & 380 & 383 & 15 & No blocking \\
\hline FC P25 E15 & 455 & 453 & 454 & 440 & 430 & 435 & 19 & No blocking \\
\hline FC P30 E5 & 410 & 400 & 405 & 394 & 381 & 388 & 17 & No blocking \\
\hline FC P30 E10 & 476 & 408 & 442 & 465 & 381 & 423 & 19 & No blocking \\
\hline FC P30 E15 & 432 & 396 & 414 & 400 & 385 & 393 & 21 & No blocking \\
\hline FC P35 E5 & 407 & 391 & 399 & 381 & 376 & 379 & 20 & No blocking \\
\hline FC P35 E10 & 436 & 390 & 413 & 400 & 381 & 392 & 21 & No blocking \\
\hline
\end{tabular}

\section{Conclusion}

Based upon the results obtained, the following conclusion are drawn:

1. In conclusion, the chemical proportion of POFA comprise reactive silica is vary from different sources of mill. The difference of the chemical constituent is due to several reasons e.g. the parts of the palm oil tree burned, particle fineness and the burning temperature. Higher reactive silica content comes from the kernel of palm oil tree. If the brunches are comprised in the burning process, the fiber of the palm oil tree brunches would produce more carbon content, which does not bring effect on strength and just remain as a filler in concrete. The reactivity of POFA particles is majorly depends on its fineness. Finer POFA particles rise the content of more reactive silica $\left(\mathrm{SiO}_{2}\right)$, and this would help in developing higher strengths and durability. Furthermore, chemical composition calcium oxide $(\mathrm{CaO})$ of Eggshell Ash is higher than Ordinary Portland Cement. Therefore, the behavior of Eggshell Ash of this study can be compared with OPC as cement replacement.

2. The workability of fresh state foamed concrete of $1800 \mathrm{~kg} / \mathrm{m}^{3}$ density incorporating POFA and Eggshells as cement replacement. This was achieved which flow ability all the samples of fresh foamed concrete have difference between 0 to $25 \mathrm{~mm}$ of slump flow and J-ring flow and had no visible blocking. According to ASTM C 1621/C $1621 \mathrm{M}^{1}$, the difference between 25 $\mathrm{mm}$ to $50 \mathrm{~mm}$ minimal to noticeable blocking and more than 50 $\mathrm{mm}$ is noticeable to extreme blocking. 


\section{Acknowledgement}

The authors would like to thank the Universiti Tun Hussein Onn Malaysia (GPPS-H019) and Research Management Centre (RMC) UTHM for the financial support for this project.

\section{References}

[1] Khaw Y H (2010). Performance of Lightweight Foamed Concrete Using Laterite as Sand Replacement. Faculty of Civil Engineering \& Earth Resources Universiti Malaysia Pahang, (December), i-67. https://doi.org/10.1017/CBO9781107415324.004

[2] Jhatial AA, Goh WI, Mohamad N, Alengaram UJ \& Mo KH (2018), Effect of polypropylene fibres on the thermal conductivity of lightweight foamed concrete. In MATEC Web of Conferences ( Vol. 150, p. 03008). EDP Sciences.

[3] Ramamurthy K, Kunhanandan Nambiar EK \& Indu Siva Ranjani G (2009), A classification of studies on properties of foam concrete. Cement and Concrete Composites, 31(6), 388-396. https://doi.org/10.1016/j.cemconcomp.2009.04.006

[4] Astro Awani (2016). Malaysians consume 1.8 million chickens daily - Ahmad Shabery on July 19, 2016, from http://english.astroawani.com/malaysia-news/malaysians- consume-1-8-million-chickens-daily-ahmad-shabery-111491

[5] Tangchirapat W, Saeting T, Jaturapitakkul C, Kiattikomol K \& Siripanichgorn A (2007), Use of waste ash from palm oil industry in concrete. Waste Management, 27(1), 81-88. https://doi.org/10.1016/j.wasman.2005.12.014

[6] Cement H \& Apparatus A (2008). Standard Specification, 1-8.

[7] Neville AM (2010). Properties of Concrete (4th ed.). London: Pearson, pp. 10-17, 65-71, 83-86.

[8] Berrocal CG, Löfgren I, Lundgren K (2014), Experimental Investigation on Rebar Corrosion in Combination with Fibers. In: Nordic Concrete Federation (Ed.), XXII Nordic Concrete Research Symposium. Nordic Concrete Federation, Reykjavik, Iceland.

[9] Khaled Marar \& Ozgur Eren (2011). Effect of cement content and water/ cement ratio on fresh concrete properties without admixtures, Department of civil Engineering, Eastern Mediterranean University Turkey.

[10] Muhamad R, Hamid ZA, Zakaria F, Abdullah A, \& Hussin MW (2006), Pofa: A potential partial cement replacement material in aerated concrete. 6th Asia Pacific Structural Engineering and Construction (APSEC 2006), (9), 5-6.

[11] Lim SK, Tan CS, Lim OY \& Lee YL, (2013). Fresh and hardened properties of lightweight foamed concrete with palm oil fuel ash as filler. Construction and Building Materials, 46(9), 39-47.

[12] Mohamad ME, Mahmood AA, Min AYY \& Khalid NHA (2016) A review of the mechanical properties of concrete containing biofillers. IOP Conference Series: Materials Science and Engineering, 160(11), 1-9.

[13] Lim OY (2012). Engineering Properties of Lightweight Foamed Concrete Incorporated with Palm Oil Fuel Ash (POFA). Universiti Tunku Abdul Rahman. Universiti Tunku Abdul Rahman.

[14] Gowsika D, Sarankokila S \& Sargunan K (2014). Experimental investigation of egg shell powder as partial replacement with cement in concrete. International Journal of Engineering Trends and Technology (IJETT), 14(8), 65-68.

[15] Freire MN \& Holanda JNF (2006). Characterization of avian eggshell waste aiming its use in a ceramic wall tile paste. Cerâmica, 52(12), 240-244.

[16] Marinamarican MH (2015). The Effect of Eggshell Powder on Concrete Brick Performance. Universiti Malaysia Pahang. Universiti Malaysia Pahang.

[17] Hama SM (2017). Improving mechanical properties of lightweight Porcelanite 4 aggregate concrete using different waste material. International Journal of Sustainable Built Environment (IJSBE), 6(6), $81-90$

[18] Venkatamuni T (2016). Effect of eggshell composite material for the replacement of conventional material. International Journal of Innovative Research and Advanced Studies (IJIRAS), 3(11), 44-48.

[19] Hwang SD, Khayat KH, Bonneau O. Performance-based specifications of selfconsolidating concrete used in structural applications. ACI Mater J 2006; 103(2):121-9.

[20] Brameshuber W, Uebachs S (2001) Practical experience with the application of selfcompacting concrete in Germany. In: Proceed- ings of $2^{\text {nd }}$ International Symposium on Self-compacting Concrete, Tokyo, Japan, pp. 687-96.

[21] Method, S. T., Ability, P., \& Concrete, S. (2013). WSDOT FOP for ASTM C 1621/C 1621M 1, (January).

[22] Ranjbar N, Mehrali M, Behnia A \& Alengaram UJ (2014). Compressive strength and microstructural analysis of fly ash / palm oil fuel ash based geopolymer mortar, 59, 532-539. https://doi.org/10.1016/j.matdes.2014.03.037

[23] Gowsika D, Sarankokila S \& Sargunan K (2014). Experimental Investigation of egg shell owder as partial replacement with, 14(2), $65-68$. 